good response to practolol this deterioration was reversed. Controlling the ventricular rate in one patient with extensive cardiac infarction and heart failure did not result in improvement, and the patient died some days later with uncontrolled heart failure. The dysrhythmias were superimposed on chronic heart failure in 11 patients and the effect of controlling the ventricular rate was less impressive, but in all patients the failure was subsequently controlled with conventional therapy, except in the patient with an atrial septal defect and gross heart failure who required peritoneal dialysis to control the failure.

\section{Discussion}

In the management of supraventricular dysrhythmias with a rapid ventricular rate digitalization remains the principal mode of therapy. Even with rapidly acting digitalis preparations, however, such as ouabain used intravenously, full digitalization may not be achieved safely unless the digitalizing dose is given over one to two hours. If direct-current shock is contemplated there are increased hazards in the fully digitalized patient. As the efficacy of practolol in this situation can be judged within minutes and alternative therapeutic possibilities are not influenced, practolol is a useful adjunct to antidysrhythmic drugs, and successful control of the ventricular rate is likely in most cases. Only six of the 32 patients failed to respond. Similar results have been reported principally in postoperative dysrhythmias and in patients with acute cardiac infarction. The use of practolol in the treatment of supraventricular tachycardias associated with Wolff-Parkinson-White syndrome has not previously been reported, and all four patients in this series failed to respond. This is in contrast to the effect of propranolol (Stock, 1966), suggesting that the antidysrhythmic effect of propranolol in this situation is related to its quinidinelike effect and not to its beta-adrenergic receptor blocking action.

As with other beta-adrenergic blocking drugs the possibility of provoking or aggravating heart failure must be considered (Stock and Dale, 1963; Stephen, 1966; Conway et al., 1968). Haemodynamic studies (Shinebourne et al., 1968; Sowton $e t$ al., 1968) have shown that $5 \mathrm{mg}$. of practolol, while slowing the heart, does not reduce the cardiac output, but in higher dosage a modest reduction in cardiac output results. Only one patient in this series showed clinical evidence of haemodynamic deterioration after $20 \mathrm{mg}$. of practolol had failed to produce a beneficial slowing effect. The risks are probably less with practolol than with other drugs such as propranolol, which in addition to its beta-adrenergic blocking action has a direct myocardial depressant effect.

The slowing effect of practolol was mediated through a direct action on the atrioventricular node in 22 of the 23 patients who responded without a return to sinus rhythm. In the remaining case the precise mechanism of slowing was not clearly established.

Our experience with long-term administration of practolol to maintain control of the ventricular rate is limited to six patients, in five of whom it was effective for periods extending up to nine months. We do not, however, consider the drug to be an alternative to digitalis, which has additional benefit other than control of rate. In some " resistant" patients practolol controls the heart rate when digitalis alone has been inadequate.

We thank Dr. R. A. Wiseman for supplies of practolol, and Dr. W. Brigden and Dr. L. McDonald for permission to study patients under their care and for advice during the preparation of this paper.

Request for reprints to Dr. G. M. Gent.

\section{REFERENCES}

Barrett, M., et al. (1967). Cardioselective Beta Blockade: Pharmacological studies with I.C.I. 50172, Macclesfield.

Brick, I., Hutchison, K. J., McDevitt, D. G., Roddie, I. C., and Shanks, R. G. (1968). British fournal of Pharmacology, 34, 127.

Conway, N., Seymour, J., and Gelson, A. (1968). British Medical fournal, 2, 213.

Gibson, D. G., Balcon, R., and Sowton, E. (1968). British Medical fournal, 3, 161.

Jewitt, D. E., Mercer, C. J., and Shillingford, J. P. (1969). Lancet, 2,

Shinebourne, E., Fleming, J., and Hamer, J. (1968). Cardiovascular $R e$ search, 2, 379.

Sowton, E., Balcon, R., Cross, D., and Frick, H. (1968). British Medical fournal, 1, 215

Stephen, S. A. (1966). American fournal of Cardiology, 18, 463.

Stock, J. P. P. (1966). American fournal of Cardiology, 18, 444.

Stock, J. P. P., and Dale, N. (1963). British Medical fournal, 2, 1230.

\title{
Rate of Disappearance of Endogenous Insulin from the Circulation after Removal of Insulinomas
}

\author{
B. J. BOUCHER,* M.D., M.R.C.P.; R. J. FRANKEL, † M.B., B.CH., M.R.C.P.; P. WALTERS, $\ddagger$ B.SC. \\ M. ABEL, $\ddagger$ B.SC.
}

\begin{abstract}
Cummary: In two patients with insulinomas a rapid $\checkmark$ rate of disappearance of insulin from the circulation was found after the tumours had been removed. In a third case the rate of disappearance was slower but the insulin was not immunologically identical to normal human insulin standards, as it was in the other two cases.
\end{abstract}

\footnotetext{
* Physician.

Lecturer, Medical

Department of Metabolism and Endocrinology, London Hospital, London E.1.
}

It has been suggested in the past that the half-time of disappearance of insulin from the circulation might be about 35 minutes using radioiodine-labelled insulin (Berson et al., 1956). Samols and Marks (1966) and Williams et al. (1968) measured the rate of fall of endogenous immunoreactive insulin in man at the cessation of prolonged glucose and glucagon infusions and found half-times of insulin disappearance of 7 to 15 minutes. As has been pointed out (Stimmler, 1966) there is no certainty that insulin secretion stops instantly in such studies, and if it did continue at all 
during the time in which insulin levels were measured a falsely high half-time would be found. Their data, however, certainly suggest that the half-time in normal adults is not longer than 7 to 15 minutes. It has been shown (Stimmler, 1967; Stimmler et al., 1969) that the rate of disappearance of injected porcine insulin (unlabelled) measured with radioimmunoassay was much faster, with a mean half-time of insulin disappearance from the plasma of 3.3 minutes in normal subjects. It is possible, however, that the measured rate of disappearance in these studies could be unphysiological owing to the doses of insulin given $(0.1$ unit $/ \mathrm{kg}$.) or to the porcine origin of the insulin, even though it was immunologically indistinguishable from human insulin in the assay system.

It was felt that a study of the rate of fall of insulin in the circulation of patients undergoing removal of functional insulinomas, in whom basal insulin secretion appeared to be suppressed at the time of operation, and whose plasma insulin was immunologically indistinguishable from extracted human insulin might provide evidence of the actual rates of disappearance of endogenous insulin from the circulation.

\section{Methods}

Blood samples were taken at intervals from an indwelling venous catheter from the subjects under anaesthesia before, during, and after the isolation and removal of the tumours during the monitoring of blood sugar levels. A very slow infusion of $4 \%$ dextrose in $0.2 \mathrm{~N}$ saline was given intravenously throughout the operation into the contralateral arm. Plasma insulin was measured by radioimmunoassay with a double precipitation method based on that of Morgan and Lazarow (1963). Human insulin standards (Novo) were used and the assay sensitivity was $1 \mu \mathrm{u} . / \mathrm{ml}$. with a reproducibility of $\pm 10 \%$. Dilutions of the sample containing the highest insulin level in each case were made and assayed in the same way. The blood sugars were measured with an autoanalyser method based on that of Hoffman (1937). A single exponential curve was fitted by the method of least squares to the series of plasma insulin levels from each patient from the time of clamping the blood supply to the tumour to the time at which the minimum levels were reached.

\section{Case Histories}

Case 1.-A boy aged 10 had a 15-month history of episodes of disturbed behaviour. Fasting hypoglycaemia $(17-37 \mathrm{mg} . / 100 \mathrm{ml}$.) and an abnormal response to intramuscular glucagon were found. In addition fasting hypercalcaemia was found (11.1-11.4 mg./ $100 \mathrm{ml}$.). At laparotomy (19 August 1969) the tail of the pancreas contained three nodules $(1.2,0.4$, and $0.4 \mathrm{~cm}$. diameter) and was removed together with the spleen. During the operation the blood sugar rose from 114 to $175 \mathrm{mg} . / 100 \mathrm{ml}$. and nine hours postoperatively reached a maximum of $248 \mathrm{mg} . / 100 \mathrm{ml}$. Carbohydrate tolerance returned to normal by the tenth day. Pathological examination revealed three $\beta$ islet cell tumours with no mitoses or signs of invasion, two of which gave positive granular cytoplasmic staining with the Gomori aldehyde fuchsin technique. The surrounding pancreas was normal. The possibility of the pluriglandular syndrome with parathyroid adenomas is being investigated.

Case 2.-A woman aged 65 had a five-month history of episodes of confusion followed later by fits with temporary paralysis. Fasting hypoglycaemia was found (22-29 mg./100 ml.). At laparotomy (18 July 1969) the tail of the pancreas contained a nodule $1.2 \mathrm{~cm}$. in diameter, and this was removed together with the spleen. Blood sugar levels rose during the operation from 139 to $150 \mathrm{mg} . / 100 \mathrm{ml}$. and reached a maximum of $375 \mathrm{mg}$. 10 hours later. Three weeks postoperatively a mildly diabetic response was found with a $50-\mathrm{g}$. oral glucose load. Pathological examination showed a $\beta$ islet cell tumour incorporating some pancreatic ducts. Tumour was also present in the lumen of a vein. No mitoses were seen and the surrounding pancreas was normal.
Case 3.-A woman aged 42 had a nine-month history of "blackouts," especially after long periods without food. Fasting hypoglycaemia was demonstrated $(32 \mathrm{mg} . / 100 \mathrm{ml}$.). At laparotomy (13 March 1969) the tail of the pancreas contained a nodule 1.5 $\mathrm{cm}$. in diameter, and was removed together with the spleen. Blood sugar levels rose from 80 to $154 \mathrm{mg} . / 100 \mathrm{ml}$. during the operation, reaching a maximum of $184 \mathrm{mg} . / 100 \mathrm{ml} .22$ hours later. One week after the operation a glucose tolerance test was normal (50-g. oral glucose) and follow-up six months later showed no abnormality. Pathological examination showed $\beta$ islet cell tumour with occasional mitoses. There were groups of tumour cells in the pancreatic connective tissue adjacent to the tumour but the surrounding pancreas was normal.

\section{Results}

The plasma insulin values obtained in each case are shown in Fig. 1. Levels of $<1 \mu \mathrm{u}$./ml. were reached in Cases 1 and 2

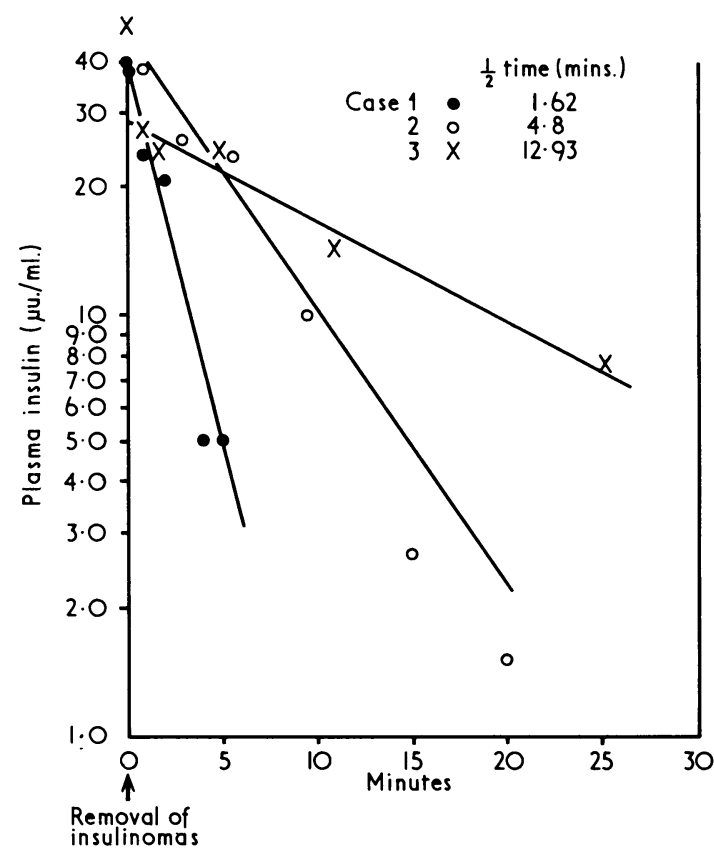

Fig. 1.-Immunoassayable plasma insulin levels plotted logarithmically in the first 30 minutes after the removal of an insulinoma in Cases 1, 2, and 3 (see text).

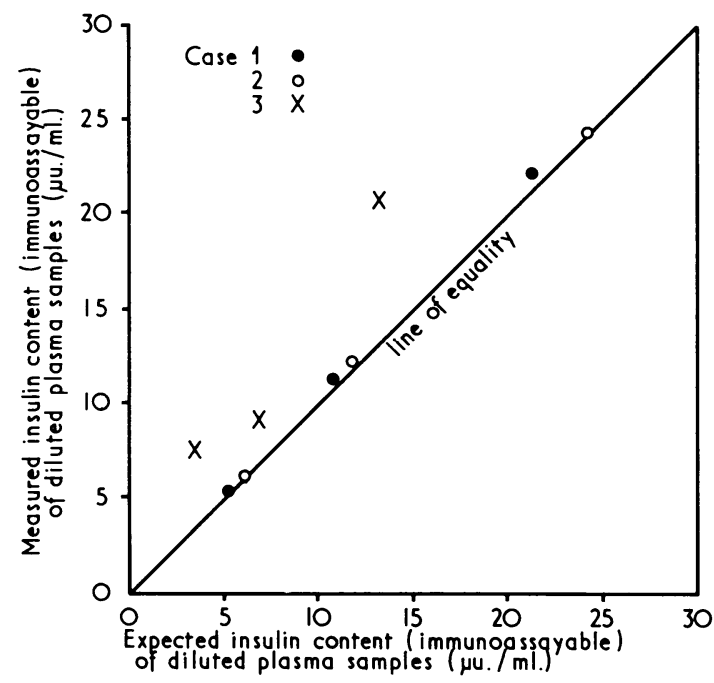

Fig. 2.-Measured versus the expected immunoassayable insulin content of plasma samples from Cases 1, 2, and 3 (see text) on dilution to $1: 2,1: 4$, and $1: 8$. 
by 7.5 and 30 minutes respectively but were never $<7.5$ $\mu \mathrm{u} . / \mathrm{ml}$. in Case 3. The insulin responses to the oral glucose loads given postoperatively were normal in all three cases. The half-times for the disappearance of insulin from the circulation were 1.6, 4.8, and 12.9 minutes in Cases 1,2 , and 3 respectively. Fig. 2 shows the results of immunoassays on the samples containing the highest levels of insulin in each case, after dilution to $1: 21: 4$, and $1: 8$. The samples from Cases 1 and 2 showed the expected levels on dilution-that is, behaved immunologically like the human insulin standardwhile the sample from Case 3 failed to assay in the same way on dilution.

\section{Discussion}

The rates of disappearance of endogenous insulin in Cases 1 and 2 were very fast, and were similar to those previously described in normal subjects given porcine insulin (Stimmler, 1967; Stimmler et al., 1969). These rates are also compatible with a theoretical prediction of insulin disappearance rate based on the known clearances of insulin by various parts of the body (Stimmler, 1966). The fall of plasma insulin to zero temporarily in Cases 1 and 2 suggests that there was no, or very little, basal insulin secretion from normal islet tissue at that time which could have interfered with the estimates of half-time in these cases, but such interference could have occurred in Case 3, in whom insulin levels did not fall to zero. Mild hyperglycaemia, however, did develop later that day in this case, suggesting some suppression of normal islet cell function, so that the finding of a slower rate of disappearance could also have been due to the presence of immunoactive material in the plasma different from the standard human insulin, which could not therefore be assayed correctly. Further studies are in progress and will be reported in due course.

We are grateful to Dr. A. S. Mason, Dr. A. Jackson, Dr. A. Robinson, Dr. M. A. Floyer, and Mr. J. E. Richardson for allowing us to study patients under their care and to Professor I. Doniach and Dr. C. Brown for the pathological reports.

\section{REFERENCES}

Berson, S. A., Yalow, R. S., Bauman, A., Rothschild, M. A., and Newerly, K. (1956). Fournal of Clinical Investigation, 35, 170

Hoffman, W. S. (1937). Fournal of Biological Chemistry, 120, 51.

Morgan, C. R., and Eazarow, A. (1963). Diabetes, 12, 115.

Samols, E., and Marks, V. (1966), Lancet, 2, 700.

Stimmler, L. (1966). Lancet, 2, 1078.

Stimmler, L. (1967). Diabetes, 16, 652.

Stimmler, L., Mashiter, K., Boucher, B. J., and Meadow, S. R. (1969) Clinical Science, 37, 371 .

Williams, R. F., Gleason, R. E., and Soeldner, J. S. (1968). Metabolism, $17,1025$.

\title{
Contact Dermatitis in Home Helps Following the Use of Enzyme Detergents
}

\author{
CHRISTINA F. J. DUCKSBURY,* M.B., CH.B., D.P.H.; V. K. DAVE, † M.B., B.CH., M.R.C.P.
}

Cummary: Twelve women in the home help service in Nottingham developed dermatitis after using enzyme detergents. A survey based on a questionary showed an incidence of $5 \%$ among those using them. The enzyme appears to act as a primary irritant.

\section{Introduction}

In July 196912 home helps employed by the City of Nottingham Health Department complained of acute and persistent dermatitis of the hands after using enzyme washing powders. All were subsequently examined at the dermatological department of the Nottingham General Hospital, where the diagnosis of dermatitis was confirmed. As similar cases may be occurring in other areas, this account of the outbreak may be of general interest.

\footnotetext{
* Senior Medical Officer, City of Nottingham.
}

† Registrar in Dermatology, Nottingham General and City Hospitals.

\section{Patch Tests}

All the patients had patch tests carried out on the upper part of the back with $0.1 \%$ solution in water each of Ariel, Daz, and Fairy Snow. Distilled water was used as a control. 